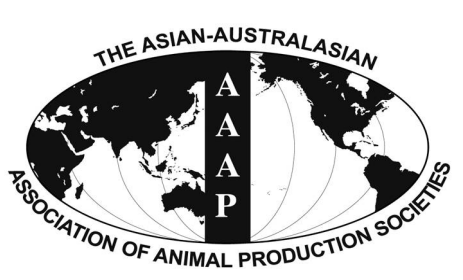

Open Access

Asian Australas. J. Anim. Sci.

Vol. 28, No. 9 : 1335-1344 September 2015

http://dx.doi.org/10.5713/ajas.14.0339

Www.ajas.info

pISSN 1011-2367 elSSN 1976-5517

\title{
Validation of Prediction Equations of Energy Values of a Single Ingredient or Their Combinations in Male Broilers
}

\author{
R. R. Alvarenga*, P. B. Rodrigues, M. G. Zangeronimo ${ }^{1}$, E. C. Oliveira, F. C. M. Q. Mariano ${ }^{2}$, \\ E. M. C. Lima, A. A. P. Garcia Jr, L. P. Naves, and N. B. S. Nardelli \\ Animal Sciences Department, Federal University of Lavras (UFLA), Lavras, MG 37200-000, Brazil
}

\begin{abstract}
A set of prediction equations to estimate the nitrogen-corrected apparent metabolizable energy (AMEn) of individual ingredients and diets used in the poultry feed industry was evaluated. The AMEn values of three energy ingredients (maize, sorghum and defatted maize germ meal), four protein ingredients (soybean meal, maize gluten meal $60 \%$ crude protein, integral micronized soy and roasted whole soybean) and four diets (three containing four feedstuffs, complex diets, and one containing only corn-soybean meal, basal diet) were determined using a metabolism assay with male broilers from 1 to 7,8 to 21,22 to 35 , and 36 to 42 days old. These values were compared to the AMEn values presented in the tables of energy composition or estimated by equation predictions based on chemical composition data of feedstuffs. In general, the equation predictions more precisely estimated the AMEn of feedstuffs when compared to the tables of energy composition. The equation AMEn (dry matter [DM] basis) $=4,164.187+51.006$ ether extract (\% in DM basis)-197.663 ash-35.689 crude fiber (\% in DM basis)-20.593 neutral detergent fiber (\% in DM basis) $\left(\mathrm{R}^{2}=0.75\right)$ was the most applicable for the prediction of the energy values of feedstuffs and diets used in the poultry feed industry. (Key Words: Energy, Prediction Equation, Feed Formulation, Poultry)
\end{abstract}

\section{INTRODUCTION}

Poultry are characterized by high nutritional requirements compared to other species of livestock. The rapid development of the poultry industry is due to the advances in genetics, health, nutrition and management (Chadd, 2007). These changes increase the nutritional requirements of poultry that require more elaborated diets. However, accurate characterization of the chemical composition and energy content of feedstuffs is required to formulate diets.

The diversity of feedstuffs and by-products used for feeding broilers requires precise knowledge of the chemical

\footnotetext{
* Corresponding Author: R. R. Alvarenga. Tel: +55-35-38293941, Fax: +55-35-38291248, E-mail: renata.alvarenga@dzo.ufla.br

${ }^{1}$ Veterinary Medicine Department, Federal University of Lavras, Lavras, MG 37200-000, Brazil.

2 Exact Science Department, Federal University of Lavras, Lavras, MG 37200-000, Brazil.

Submitted May 9, 2014; Revised Jul. 12, 2014; Accepted Sept. 5, 2014
}

composition and metabolizable energy (ME) of feed ingredients to allow for the formulation of nutritionally and economically balanced diets (Mariano et al., 2012). Errors in diet formulation can limit broiler performance, causing costly losses for farmers and the meat industry.

It is well established that dietary energy influences poultry development. Both low (Nunes et al., 2012) and high (Corduk et al., 2007) energy levels have been reported to impair performance and increase fat content (Min et al., 2012), which is undesirable from a consumer standpoint. Because most feedstuffs used in broiler diets do not provide sufficient energy for proper animal development, it is common to add lipid sources to formulations, including oils of vegetable origin. Oil may improve the poultry performance due to extra-caloric effects, which increase the availability of dietary nutrients (Murugesan et al., 2013). On the other hand, excessive levels of lipids may increase the fat deposition (Wongsuthavas et al., 2008).

To satisfactorily meet energy requirements and formulate adequate diets for broilers, it is necessary to know 
the energy values of feedstuffs. A common way to express the energy value of feedstuffs is the nitrogen-corrected apparent metabolizable energy (AMEn) value. Currently, several different methods are available to determine the energy content of feedstuffs for poultry, such as biological assays (in vivo) involving the collection of total excreta (Sibbald and Slinger, 1963), precision feeding (Sibbald, 1976) or the rapid method (Farrell, 1978), as well as nonbiological assays (in vitro tests, Longland, 1991), tables of chemistry and energy composition of feedstuffs (NRC, 1994) and prediction equations based on the chemical composition of the feedstuffs (Alvarenga et al., 2011). Tables and equation predictions offer the advantage of quickly acquiring AMEn values of feedstuffs without the use of animals for bioassays. However, the use of tables may result in errors in formulations because illustrated values represent an average of several measurements from previous animal studies. Conversely, the use of prediction equations may be a more accurate method given that the chemical composition of the feedstuffs is used.

Such equations were recently successfully tested by Alvarenga et al. (2011) using corn-soybean diets for broilers. However, the use of the equations has not yet been validated for diets combining more than two feedstuffs. Thus, the objective of the current study was to evaluate the ability of the described prediction equations previously generated by meta-analysis to estimate the AMEn values of protein and energy concentrate feedstuffs of alternative diets containing more than two types of feed for male broilers.

\section{MATERIALS AND METHODS}

The experiment was conducted at the Avian Centre, Department of Animal Science, Federal University of Lavras, MG, Brazil. The experimental protocol number 023/12 was approved by the Bioethics Committee of the
Federal University of Lavras.

\section{Ingredients and tested diets}

A total of three energy ingredients (maize, sorghum and defatted maize germ meal) and four protein concentrate ingredients (soybean meal, maize gluten meal 60\% crude protein $[\mathrm{CP}]$, integral micronized soy and roasted whole soybean) were simultaneously obtained from different commercial establishments based on the availability in Brazil and chemical variation between the feedstuffs. Using these ingredients, three complex diets (CDs) with four feedstuffs were formulated to meet the nutritional requirements of the broilers. For each $\mathrm{CD}$, the quantities of each ingredient (as-feed) were as follows:

Diet 1: maize $(35.9 \%)+$ soybean meal $(22.9 \%)+$ sorghum $(30.0 \%)+$ maize gluten meal $(5.0 \%)$

Diet 2: maize $(52.8 \%)+$ soybean meal $(23.9 \%)+$ defatted maize germ meal (10.0\%)+integral micronized soy $(8.0 \%)$

Diet 3: maize $(30.9 \%)+$ soybean meal $(24.4 \%)+$ sorghum $(30.0 \%)+$ roasted whole soybean $(8.0 \%)$.

During the formulation of diets, energy values and chemical composition of feedstuffs were obtained from the tables of chemistry and energy composition (Rostagno et al., 2011). Subsequently, food samples had the chemical and energy composition analyzed immediately upon collection (Table 1).

\section{Experimental procedures}

The experimental diets included four complete diets (three CDs and one corn-soybean meal diet, basal diet) and seven manufactured diets by substituting the basal diet with protein concentrate feedstuffs in $30.0 \%$ or the energy concentrate feedstuffs in $40.0 \%$. Each of the 11 different diets was fed to four male chicks (Cobb 500) in a metabolic cage ( 6 cages per diet for a total of 24 chicks per diet) from 1 to 7,8 to 21,22 to 35 , and 36 to 42 days old. The cages

Table 1. Chemical composition of the feedstuffs $(\%, D M)^{1}$

\begin{tabular}{|c|c|c|c|c|c|c|c|c|}
\hline \multirow{2}{*}{ Feedstuff } & \multicolumn{8}{|c|}{ Composition } \\
\hline & $\mathrm{DM}(\%)$ & GE $(\mathrm{MJ} / \mathrm{kg})$ & CP (\%) & $\mathrm{EE}(\%)$ & CF (\%) & NDF (\%) & $\operatorname{ADF}(\%)$ & Ash (\%) \\
\hline Maize & 89.2 & 16.55 & 7.9 & 3.6 & 2.3 & 11.8 & 3.4 & 1.6 \\
\hline Sorghum & 89.9 & 15.12 & 7.9 & 2.4 & 2.0 & 12.7 & 3.9 & 1.6 \\
\hline Defatted corn germ meal & 92.3 & 19.04 & 15.7 & 4.5 & 10.7 & 44.0 & 16.2 & 1.6 \\
\hline Soybean meal & 90.3 & 17.86 & 42.2 & 1.7 & 6.4 & 13.6 & 8.9 & 6.0 \\
\hline Maize gluten meal $60 \% \mathrm{CP}$ & 92.6 & 22.25 & 61.5 & 3.8 & 1.0 & 2.2 & 14.0 & 1.4 \\
\hline Integral micronized soy & 95.9 & 23.08 & 36.1 & 22.4 & 6.2 & 8.5 & 5.1 & 4.9 \\
\hline Roasted whole soybean & 95.2 & 22.77 & 33.6 & 19.8 & 8.4 & 17.6 & 13.4 & 5.5 \\
\hline Average & 92.2 & 19.53 & 29.3 & 8.3 & 5.3 & 15.8 & 9.3 & 3.2 \\
\hline Standard deviation & 2.4 & 3.0 & 18.4 & 8.2 & 3.4 & 12.3 & 4.9 & 2.0 \\
\hline Minimum & 89.2 & 15.12 & 7.9 & 1.7 & 1.0 & 2.2 & 3.4 & 1.4 \\
\hline Maximum & 95.9 & 23.08 & 61.5 & 22.4 & 10.7 & 44.0 & 16.2 & 6.0 \\
\hline
\end{tabular}

DM, dry matter; GE, gross energy; CP, crude protein; EE, ether extract; CF, crude fiber; NDF, neutral detergent fiber; ADF, acid detergent fiber.

${ }^{1}$ Analysis was performed in the Animal Nutrition Laboratory of the Animal Science Department of Federal University of Lavras. 
$(50 \times 50 \times 50 \mathrm{~cm})$ were located in a room with settings partly controlled through digital devices (Humitech II; Full Gauge, Canoas, Brazil) and artificial light for 24 hours and equipped with shaped feeders and drinkers and aluminum trays to collect the excrements. The ambient temperature was adjusted to $32^{\circ} \mathrm{C}$ during the first week of age of the broilers and was then decreased weekly according to lineage recommendations (Broiler Management Guide, Cobb 500, 2008a) until a final temperature of $19^{\circ} \mathrm{C}$ was reached in the sixth week of age.

Broilers were kept in an environmentally controlled room at a temperature of $26^{\circ} \mathrm{C}$ under $24-\mathrm{h}$ incandescent lighting, with free access to feed and water.

The basal diet consisted of maize and soybean meal with $19.5 \%$ crude protein. The estimated energy value and digestibility of nutrients in the basal diet was $12.98 \mathrm{MJ} / \mathrm{kg}$ of $\mathrm{ME}, 1.08 \%$ digestible lysine, $0.787 \%$ digestible methionine plus cystine, $0.732 \%$ calcium, and $0.342 \%$ available phosphorus, according to Rostagno et al. (2011).

Total excreta output (Dourado et al., 2010) and feed intake were determined on the last three days of each phase. Total daily excreta collections were pooled within a cage, weighed and frozen for future analysis. Before analysis, representative excreta samples $( \pm 300 \mathrm{~g})$ were dried in a forced air oven $\left(65^{\circ} \mathrm{C}\right)$ until a constant weight. After drying, excreta samples were ground in a hammer mill with a 1.0 $\mathrm{mm}$ screen and then stored at $4^{\circ} \mathrm{C}$ prior to chemical analysis.

\section{Chemical analyses}

All analyses were performed in duplicate. Ingredients were analyzed for dry matter (DM) by oven-drying the sample (method 934.01), ash by muffle furnace incineration (method 942.05), CP by the Kjeldahl method (method 954.01), ether extract (EE) without acid hydrolysis (method 920.39), acid detergent fiber (ADF) (index no. 973.18) and crude fiber (CF) (method 962.09) according to the AOAC (1995). Neutral detergent fiber (NDF) content was analyzed as previously described by Van Soest et al. (1991), with samples first treated with $\alpha$-amylase before NDF extraction. Gross energy (GE) was determined using a bomb calorimeter (model 1261, Parr Instrument Company, Moline, IL, USA).

Experimental diets (without feed substitution) and excreta were analyzed for DM, CP, and GE.

\section{Nitrogen-corrected apparent metabolizable energy determination}

The AMEn values of various diets were calculated by correction to zero nitrogen retention according to Hill and Anderson (1958) using the following formula with appropriate corrections made for differences in DM content:
AMEn of diets $=\left[\left(\right.\right.$ feed intake $\left.\times \mathrm{GE}_{\text {diet }}\right)-($ excreta output $\left.\left.\times \mathrm{GE}_{\text {excreta }}+8.22 \times \mathrm{NB}\right)\right] /\left(\right.$ feed intake $\left.\times \mathrm{DM}_{\text {diet }}\right)$

where $\mathrm{GE}_{\text {diet }}$ is the GE of diet, $\mathrm{GE}_{\text {excreta }}$ is the GE of the excreta and $\mathrm{DM}_{\text {diet }}$ is the $\mathrm{DM}$ of the diet.

The AMEn of each feedstuff, which was determined by an in vivo bioassay, was calculated using the equation proposed by Matterson et al. (1965):

AMEn of feedstuffs

$=\mathrm{AMEn}_{\mathrm{bd}}+\left\{\left(\mathrm{AMEn}_{\mathrm{td}}-\mathrm{AMEn}_{\mathrm{bd}}\right) /[\right.$ inclusion level of test ingredient on basal diet $(\mathrm{g} / \mathrm{kg}) / 1,000]\}$

where $\mathrm{AMEn}_{\mathrm{td}}$ is the AMEn of the tested diet and $\mathrm{AMEn}_{\mathrm{bd}}$ is the AMEn of the basal diet.

Similarly, the AMEn value of feedstuffs ( $\mathrm{kcal} / \mathrm{kg} \mathrm{DM}$ ) was determined using prediction equations based on chemical compositions ( $\%$ DM) and then converted to $\mathrm{MJ} / \mathrm{kg}$ by multiplying by a factor of 0.004187 . The following systems of equations predictions were utilized:

i) Equations used specifically to predict the AMEn values of maize and soybean meal included in maizesoybean diets for broilers:

EQ1: AMEn $=4,021.8-227.55$ ash (for maize, defatted maize germ meal, maize gluten meal 60) $\left(\mathrm{R}^{2}=0.92 ; \mathrm{n}=11\right)$ and $\mathrm{AMEn}=-822.33+69.54 \mathrm{CP}-45.26 \mathrm{ADF}+90.81 \mathrm{EE}$ (for soybean meal, integral micronized soy and roasted whole soybean) $\left(\mathrm{R}^{2}=0.92 ; \mathrm{n}=8\right)$, presented by Alvarenga et al. (2013).

EQ2: $\mathrm{AMEn}=4,164.187+51.006 \mathrm{EE}-197.663 \mathrm{ash}-$ 35.689CF-20.593NDF (for energy and protein concentrate feedstuffs $)\left(\mathrm{R}^{2}=0.75 ; \mathrm{n}=293\right)$, presented by Mariano et al. (2012) and Alvarenga et al. (2013).

EQ3: $\mathrm{AMEn}=4,144.914+53.137 \mathrm{EE}-204.644 \mathrm{ash}-$ 26.214CF-20.26NDF (for energy and protein concentrate feedstuffs $)\left(\mathrm{R}^{2}=0.71 ; \mathrm{n}=293\right)$ presented by Mariano et al. (2012).

ii) Equations proposed by Nascimento et al. (2009; 2011a, b) and confirmed by Alvarenga et al. (2011) to be applicable for the prediction of the AMEn values of feedstuffs for broilers:

EQ4: $\mathrm{AMEn}=4,371.18-26.48 \mathrm{CP}+30.65 \mathrm{EE}-126.93 \mathrm{ash}$ $-52.26 \mathrm{CF}-25.14 \mathrm{NDF}+24.40 \mathrm{ADF}$ (for energy concentrate feedstuffs $)\left(\mathrm{R}^{2}=0.81\right.$; relative standard deviation $(\mathrm{RSD})=$ $0.4689 ; \mathrm{p}<0.0001 ; \mathrm{n}=375)$ and $\mathrm{AMEn}=2707.71+$ 58.63EE-16.06NDF (for protein concentrate feedstuffs) $\left(\mathrm{R}^{2}\right.$ $=0.81 ; \mathrm{RSD}=0.4847 ; \mathrm{p}<0.0001 ; \mathrm{n}=199)$.

EQ5: $\mathrm{AMEn}=4,101.33+56.28 \mathrm{EE}-232.97$ ash24.86NDF+10.42ADF (for energy and protein concentrate feedstuffs $)\left(\mathrm{R}^{2}=0.84 ; \mathrm{RSD}=0.4137 ; \mathrm{p}<0.0001 ; \mathrm{n}=574\right)$.

EQ6: $\mathrm{AMEn}=4,095.41+56.84 \mathrm{EE}-225.26 \mathrm{ash}-22.24 \mathrm{NDF}$ 
(for energy and protein concentrate feedstuffs) $\left(\mathrm{R}^{2}=0.83\right.$; $\mathrm{RSD}=0.4171 ; \mathrm{p}<0.0001 ; \mathrm{n}=574)$.

iii) Software "calculator" proposed by Rostagno et al. (2005)

\section{Statistical analysis}

The predicted AMEn values calculated using each equation were compared to those determined by in vivo bioassays. The validation procedure involved fitting a simple linear regression model $(\mathrm{Y}=\mathrm{a}+\mathrm{bX})$ of observed (dependent variable) to predicted values (independent variable) using simultaneous hypotheses tested by an $\mathrm{F}$ test as previously described by Mayer et al. (1994):

$$
\begin{aligned}
& \mathrm{H}_{0}: \beta_{0}=0 \\
& \mathrm{H}_{0}: \beta_{1}=1
\end{aligned}
$$

The predicted and observed values were considered similar when both null hypotheses were not rejected. Estimated standard error, which measures the variability around the regression line, was calculated based on the set of predicted values (Neter et al., 1985):

$$
\mathrm{S}_{\text {est }}=\sqrt{\frac{\sum\left(\mathrm{Y}-\mathrm{Y}^{\prime}\right)^{2}}{N-2}}
$$

where $\mathrm{S}_{\mathrm{est}}=$ standard error of estimation; $\mathrm{Y}=$ predicted value; $\mathrm{Y}^{\prime}=$ observed value; $\mathrm{N}-2=$ degrees of freedom of the residue obtained in the regression variation analysis.

All statistical analyses were performed using SAS (2004). For all statistical procedures, $\alpha=0.05$ was adopted.

The estimated values for each feedstuff were used to predict the AMEn values of tested diets commonly used in the poultry industry (i.e., basal diet and the three diets with more than two feedstuffs). Thus, the accuracy of each prediction equation to calculate the AMEn values of complete poultry diets based on the AMEn values of the feedstuffs was evaluated. In parallel, an analogy was made with the use of AMEn values of the feedstuffs estimated by the energy composition tables (Rostagno et al., 2011) or obtained by in vivo assay.

\section{RESULTS}

The AMEn values of individual feedstuff and diets determined by in vivo bioassay, their respective standard errors, and those calculated using prediction equations are shown in Table 2. The estimation of standard error between the observed and calculated values by prediction equations is shown in Table 3, and the parameter estimates with the respective probability values ( $\mathrm{F}$ test) for the null hypothesis and regression coefficient $\left(\mathrm{R}^{2}\right)$ between the observed and predicted values for AMEn of feedstuffs and diets are shown in Table 4.

The AMEn values of feedstuffs were similar between

\begin{tabular}{|c|c|c|c|c|c|c|c|c|c|c|c|c|}
\hline \multirow{2}{*}{ Feedstuff or diets } & \multicolumn{4}{|c|}{ Broiler age group (days) } & \multicolumn{8}{|c|}{ Estimation methods $^{1}$} \\
\hline & 1 to $7 \mathrm{~d}$ & 8 to $21 \mathrm{~d}$ & 22 to $35 \mathrm{~d}$ & 36 to $42 \mathrm{~d}$ & E1 & E2 & E3 & E4 & E5 & E6 & E7 & E8 \\
\hline \multicolumn{13}{|l|}{ Feedstuffs } \\
\hline Maize (M) & $15.03(0.42)$ & $14.94(0.50)$ & $14.99(0.41)$ & $14.85(0.47)$ & 16.18 & 15.14 & 15.30 & 15.32 & 15.33 & 16.28 & 15.19 & 14.27 \\
\hline Sorghum & $14.04(0.59)$ & $13.81(0.30)$ & $14.39(0.61)$ & $14.08(0.35)$ & 15.19 & 15.19 & 15.02 & 15.03 & 15.21 & 16.07 & 14.84 & 13.57 \\
\hline Defatted corn germ meal (DC) & $9.41(0.50)$ & $9.00(0.29)$ & $9.10(0.33)$ & $9.05(0.36)$ & 14.68 & 15.19 & 11.20 & 11.64 & 10.36 & 16.19 & 12.23 & 12.15 \\
\hline Soybear & $9.99(0.70)$ & $9.69(0$. & 9.79( & $9.67(0.56)$ & 10.63 & 9.00 & 10.00 & 10.04 & 10.94 & 10.85 & 9.95 & 9.13 \\
\hline Maize gluter & $15.49(0.74)$ & $16.50(0.58)$ & $16.56(0.39)$ & $16.84(0.80)$ & 16.99 & 14.60 & 16.69 & 16.65 & 12.17 & 17.20 & 16.47 & 16.07 \\
\hline Integral & $16.63(0.53)$ & $15.98(0.58)$ & $15.88(0.64)$ & $16.29(0.49)$ & 16.55 & 15.40 & 16.44 & 16.68 & 16.48 & 17.22 & 17.03 & 15.18 \\
\hline Roasted whole soy & $13.77(0.64)$ & $13.29(0.35)$ & $13.94(0.45)$ & $13.68(0.71)$ & 15.19 & 12.08 & 14.16 & 14.48 & 15.49 & 16.11 & 14.91 & 14.00 \\
\hline \multicolumn{13}{|l|}{ Experimental diets } \\
\hline $\mathrm{M}+\mathrm{SM}+\mathrm{S}+\mathrm{MG}$ & $13.74(0.32)$ & $14.44(0.18)$ & $14.41(0.39)$ & $14.53(0.18)$ & 14.71 & 13.84 & 14.18 & 14.20 & 14.20 & 15.07 & 14.06 & 13.15 \\
\hline $\mathrm{M}+\mathrm{SM}+\mathrm{DM}+\mathrm{IM}$ & $13.36(0.10)$ & $13.49(0.24)$ & $13.65(0.30)$ & $14.00(0.17)$ & 14.66 & 13.68 & 13.68 & 13.77 & 13.81 & 14.97 & 13.77 & 12.93 \\
\hline $\mathrm{M}+\mathrm{SM}+\mathrm{S}+\mathrm{RW}$ & $13.63(0.22)$ & $13.56(0.06)$ & $14.52(0.16)$ & $14.17(0.10)$ & 14.74 & 13.76 & 14.18 & 14.22 & 14.53 & 15.17 & 14.14 & 13.20 \\
\hline $\mathrm{M}+\mathrm{SM}$ & $13.38(0.10)$ & $13.50(0.12)$ & $14.20(0.16)$ & $14.96(0.11)$ & 14.89 & 13.72 & 14.14 & 14.16 & 14.41 & 15.02 & 14.05 & 13.21 \\
\hline
\end{tabular}

Table 2. Nitrogen-corrected apparent metabolizable energy $(\mathrm{MJ} / \mathrm{kg} \mathrm{DM})$ and standard deviation of individual feedstuffs and diets obtained using metabolism assays $(n=6)$ in broilers of different age groups or by different estimation methods

DM, dry matter; AMEn, nitrogen-corrected apparent metabolizable energy; CP, crude protein; ADF, acid detergent fiber; EE, ether extract; CF, crude fiber; NDF, neutral detergent fiber.

${ }^{1} \mathrm{E} 1$ : Tables of chemistry and energy composition of feedstuffs (Rostagno et al., 2011)

E2: Equations presented by Alvarenga et al. (2013): $\mathrm{AMEn}=4,021.8-227.55 \mathrm{ash}$ and AMEn $=-822.33+69.54 \mathrm{CP}-45.26 \mathrm{ADF}+90.81 \mathrm{EE}$

E3: General equation 1 proposed by Mariano et al. (2012): AMEn =4,164.187+51.006EE-197.663ash-35.689CF-20.593NDF.

E4: General equation 2 proposed by Mariano et al. (2012): $\mathrm{AMEn}=4,144.914+53.137 \mathrm{EE}-204.644 \mathrm{ash}-26.214 \mathrm{CF}-20.26 \mathrm{NDF}$.

E5: Equations proposed by Nascimento et al. $(2011 \mathrm{a}, \mathrm{b})$ : AMEn $=4,371.18-26.48 \mathrm{CP}+30.65 \mathrm{EE}-16.93 \mathrm{ash}-52.26 \mathrm{CF}-25.14 \mathrm{NDF}+24.40 \mathrm{ADF}$ and $\mathrm{AMEn}=$ 2707.71+58.63EE-16.06NDF.

E6: General equation 1 proposed by Nascimento et al. (2009): $\mathrm{AMEn}=4,101.33+56.28 \mathrm{EE}-232.97 \mathrm{ash}-24.86 \mathrm{NDF}+10.42 \mathrm{ADF}$.

E7: General equation 2 proposed by Nascimento et al. (2009): AMEn $=4,095.41+56.84 \mathrm{EE}-225.26 \mathrm{ash}-22.24 \mathrm{NDF}$.

E8: Software "calculator" elaborated by Rostagno et al. (2005). 
Table 3. Estimated standard error and parameter estimates with their respective probability values (F test) for the null hypothesis and regression coefficient $\left(\mathrm{R}^{2}\right)$ between observed and predicted AMEn values of feedstuffs evaluated in broilers of different age groups $(\mathrm{n}=$ 5)

\begin{tabular}{|c|c|c|c|c|c|c|}
\hline \multirow{2}{*}{$\begin{array}{l}\text { Estimative } \\
\text { methods }{ }^{1}\end{array}$} & \multirow{2}{*}{$\begin{array}{c}\text { Estimative- } \\
\text { standard error }\end{array}$} & \multicolumn{2}{|c|}{ Intercept } & \multicolumn{2}{|c|}{ Slope } & \multirow{2}{*}{$\mathrm{R}^{2}$} \\
\hline & & Estimate & p value $^{\mathrm{a}}$ & Estimate & $\mathrm{p}$ value $^{\mathrm{b}}$ & \\
\hline & & \multicolumn{5}{|c|}{ - } \\
\hline E1 & 2.65 & -1.83 & 0.75 & 1.017 & 0.96 & 0.61 \\
\hline E2 & 2.86 & 5.52 & 0.41 & 0.577 & 0.38 & 0.26 \\
\hline E3 & 1.08 & -1.13 & 0.55 & 1.035 & 0.79 & 0.93 \\
\hline E4 & 1.25 & -1.52 & 0.47 & 1.052 & 0.72 & 0.92 \\
\hline E5 & 1.79 & 1.15 & 0.79 & 0.903 & 0.75 & 0.66 \\
\hline E6 & 3.50 & 0.50 & 0.94 & 0.827 & 0.70 & 0.44 \\
\hline E7 & 1.49 & -1.52 & 0.57 & 1.044 & 0.81 & 0.88 \\
\hline E8 & 1.52 & -0.59 & 0.88 & 1.044 & 0.88 & 0.75 \\
\hline E1 & 2.85 & -3.28 & 0.59 & 1.102 & 0.80 & 0.63 \\
\hline E2 & 3.04 & 4.93 & 0.49 & 0.607 & 0.44 & 0.25 \\
\hline E3 & 1.23 & -2.43 & 0.19 & 1.116 & 0.35 & 0.95 \\
\hline E4 & 1.46 & -2.74 & 0.23 & 1.126 & 0.41 & 0.93 \\
\hline E5 & 2.42 & 2.09 & 0.71 & 0.818 & 0.66 & 0.48 \\
\hline E6 & 3.74 & -0.47 & 0.95 & 0.878 & 0.80 & 0.43 \\
\hline E7 & 1.75 & -2.54 & 0.41 & 1.103 & 0.62 & 0.86 \\
\hline E8 & 1.55 & -2.08 & 0.59 & 1.142 & 0.62 & 0.78 \\
\hline & & & ------- & ays old ---- & ---------- & \\
\hline E1 & 2.69 & -2.89 & 0.64 & 1.09 & 0.82 & 0.62 \\
\hline E2 & 3.03 & 5.44 & 0.45 & 0.586 & 0.42 & 0.23 \\
\hline E3 & 1.03 & -2.16 & 0.23 & 1.111 & 0.36 & 0.95 \\
\hline E4 & 1.26 & -2.48 & 0.27 & 1.122 & 0.42 & 0.93 \\
\hline E5 & 2.27 & 1.87 & 0.73 & 0.85 & 0.70 & 0.52 \\
\hline E6 & 3.55 & -0.25 & 0.97 & 0.877 & 0.80 & 0.43 \\
\hline E7 & 1.57 & -2.28 & 0.46 & 1.099 & 0.63 & 0.87 \\
\hline E8 & 1.53 & -1.79 & 0.64 & 1.136 & 0.63 & 0.78 \\
\hline E1 & 2.76 & -3.76 & 0.55 & $\begin{array}{c}\text { ays old --- } \\
1.146\end{array}$ & 0.72 & 0.64 \\
\hline E2 & 3.09 & 4.91 & 0.51 & 0.622 & 0.48 & 0.24 \\
\hline E3 & 1.11 & -2.86 & 0.13 & 1.158 & 0.21 & 0.96 \\
\hline E4 & 1.32 & -3.21 & 0.16 & 1.171 & 0.27 & 0.94 \\
\hline E5 & 2.45 & 1.83 & 0.75 & 0.851 & 0.72 & 0.48 \\
\hline E6 & 3.61 & -1.00 & 0.90 & 0.923 & 0.87 & 0.44 \\
\hline E7 & 1.62 & -3.06 & 0.33 & 1.152 & 0.47 & 0.88 \\
\hline E8 & 1.57 & -2.58 & 0.51 & 1.193 & 0.51 & 0.80 \\
\hline
\end{tabular}

AMEn, nitrogen-corrected apparent metabolizable energy; CP, crude protein; ADF, acid detergent fiber; EE, ether extract; CF, crude fiber; NDF, neutral detergent fiber.

${ }^{1}$ E1: Tables of chemistry and energy composition of feedstuffs (Rostagno et al., 2011).

E2: Equations presented by Alvarenga et al. (2013): $\mathrm{AMEn}=4,021.8-227.55 \mathrm{ash}$ and $\mathrm{AMEn}=-822.33+69.54 \mathrm{CP}-45.26 \mathrm{ADF}+90.81 \mathrm{EE}$.

E3: General equation 1 proposed by Mariano et al. (2012): $\mathrm{AMEn}=4,164.187+51.006 \mathrm{EE}-197.663 \mathrm{ash}-35.689 \mathrm{CF}-20.593 \mathrm{NDF}$.

E4: General equation 2 proposed by Mariano et al. (2012): $\mathrm{AMEn}=4,144.914+53.137 \mathrm{EE}-204.644 \mathrm{ash}-26.214 \mathrm{CF}-20.26 \mathrm{NDF}$.

E5: Equations proposed by Nascimento et al. $(2011 \mathrm{a}, \mathrm{b}): \mathrm{AMEn}=4,371.18-26.48 \mathrm{CP}+30.65 \mathrm{EE}-16.93 \mathrm{ash}-52.26 \mathrm{CF}-25.14 \mathrm{NDF}+24.40 \mathrm{ADF}$ and $\mathrm{AMEn}=$ 2707.71+58.63EE-16.06NDF

E6: General equation 1 proposed by Nascimento et al. (2009): AMEn = 4,101.33+56.28EE-232.97ash-24.86NDF+10.42ADF.

E7: General equation 2 proposed by Nascimento et al. (2009): AMEn =4,095.41+56.84EE-225.26ash-22.24NDF.

E8: Software "calculator" elaborated by Rostagno et al. (2005).

${ }^{\mathrm{a}} \mathrm{H}_{0}: \beta_{\mathrm{o}}=0 ; \mathrm{H}_{\mathrm{a}}: \beta_{\mathrm{o}} \neq 0 .{ }^{\mathrm{b}} \mathrm{H}_{0}: \beta_{1}=1 ; \mathrm{H}_{\mathrm{a}}: \beta_{1} \neq 1$.

broilers of different ages. Greater variation (8\%) was observed with maize gluten meal, and higher energy values were found in older broilers. Considering the different systems to obtain the AMEn values of the feedstuffs, the statistical analysis of the intercept and the slope of the straight line in all the studied ages was consistent $(\mathrm{p}>0.05)$ with the null hypothesis $\left(\mathrm{H}_{0}: \beta_{0}=0\right.$ and $\left.\mathrm{H}_{0}: \beta_{1}=1\right)$, indicating that the observed values for $\mathrm{AMEn}$ are equivalent 
Table 4. Estimated standard error and parameter estimates with their respective probability values (F test) for the null hypothesis and regression coefficient $\left(\mathrm{R}^{2}\right)$ between the observed and predicted AMEn values of experimental diets evaluated in broilers of different age groups $(\mathrm{n}=4)$

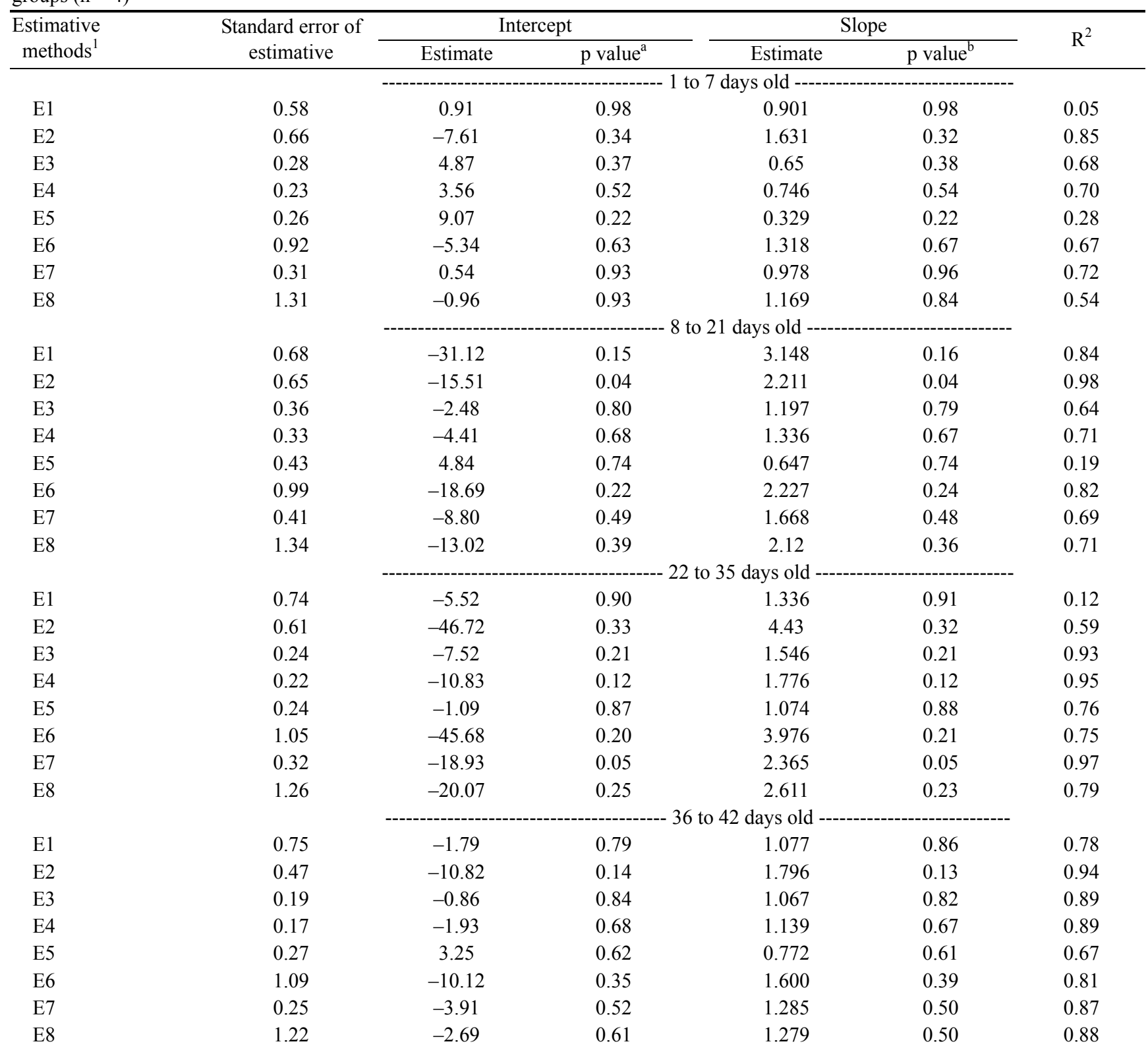

AMEn, nitrogen-corrected apparent metabolizable energy; CP, crude protein; ADF, acid detergent fiber; EE, ether extract; CF, crude fiber; NDF, neutral detergent fiber.

${ }^{1}$ E1: Tables of chemistry and energy composition of feedstuffs (Rostagno et al., 2011)

E2: Equations presented by Alvarenga et al. (2013): AMEn $=4,021.8-227.55$ ash and AMEn $=-822.33+69.54 \mathrm{CP}-45.26 \mathrm{ADF}+90.81 \mathrm{EE}$.

E3: General equation 1 proposed by Mariano et al. (2012): $\mathrm{AMEn}=4,164.187+51.006 \mathrm{EE}-197.663 \mathrm{ash}-35.689 \mathrm{CF}-20.593 \mathrm{NDF}$.

E4: General equation 2 proposed by Mariano et al. (2012): AMEn = 4,144.914+53.137EE-204.644ash-26.214CF-20.26NDF.

E5: Equations proposed by Nascimento et al. $(2011 \mathrm{a}, \mathrm{b}): \mathrm{AMEn}=4,371.18-26.48 \mathrm{CP}+30.65 \mathrm{EE}-16.93 \mathrm{ash}-52.26 \mathrm{CF}-25.14 \mathrm{NDF}+24.40 \mathrm{ADF}$ and $\mathrm{AMEn}=$ 2707.71+58.63EE-16.06NDF.

E6: General equation 1 proposed by Nascimento et al. (2009): $\mathrm{AMEn}=4,101.33+56.28 \mathrm{EE}-232.97 \mathrm{ash}-24.86 \mathrm{NDF}+10.42 \mathrm{ADF}$.

E7: General equation 2 proposed by Nascimento et al. (2009): AMEn = 4,095.41+56.84EE-225.26ash-22.24NDF.

E8: Software "calculator" elaborated by Rostagno et al. (2005).

${ }^{\mathrm{a}} \mathrm{H}_{0}: \beta_{\mathrm{o}}=0 ; \mathrm{H}_{\mathrm{a}}: \beta_{\mathrm{o}} \neq 0 .{ }^{\mathrm{b}} \mathrm{H}_{0}: \beta_{1}=1 ; \mathrm{H}_{\mathrm{a}}: \beta_{1} \neq 1$.

to those predicted by the equations in all phases of the development of the poultry (Table 3 ). At all ages, the lowest estimated standard errors were obtained using the general equation $(\mathrm{AMEn}=4,164.187+51.006 \mathrm{EE}-197.663 \mathrm{ash}-$
35.689CF-20.593NDF) that was originally proposed by Mariano et al. (2012). For the $\mathrm{R}^{2}$ values, this prediction equation presented high values.

To estimate the AMEn values of diets using the AMEn 
values of feedstuffs, most of the estimation methods were effective because the null hypothesis $\left(\mathrm{H}_{0}: \beta_{0}=0\right.$ and $\mathrm{H}_{0}: \beta_{1}$ $=1$ ) was confirmed (Table 4). The lowest estimated standard errors were obtained using an additional general equation $(\mathrm{AMEn}=4,144.914+53.137 \mathrm{EE}-204.644 \mathrm{ash}-$ 26.214CF-20.26NDF) proposed by Mariano et al. (2012). The $\mathrm{R}^{2}$ values obtained with this prediction equation were considerably high $(>0.70)$, mainly from 22 to 35 and 36 to 42 days of age. For the other growth phases, higher precision was obtained using the equations presented by Alvarenga et al. (2013).

\section{DISCUSSION}

In general, the feedstuffs used in the current study had different chemical values compared to those presented in the summary tables of chemistry and energy composition of feedstuffs (NRC, 1994; Lesson and Summers, 1997; Rostagno et al., 2011; Batal and Dale, 2012) and also in poultry studies (Frikha et al., 2012; Silva et al., 2012; Anuradha et al., 2013). Various factors, such as soil fertility, planting and fertilization conditions, climate, genetics of cultivars, storage and processing of grain, are known to influence such values. This variability in chemical composition of feedstuffs explains the observed variation in the AMEn values of the main ingredients used in poultry diets, highlighting the importance and need for new methodologies to estimate the energy values of feedstuffs.

Based on the results of the current study, the general equations proposed by Mariano et al. (2012) led to the lowest estimated standard error in the predicted AMEn values of feedstuffs and experimental diets at all growth stages of broilers, particularly compared to the tables of chemistry and energy composition of feedstuffs (Rostagno et al., 2011). These results indicate that the use of prediction equations may generate more accurate energy values and can even be used to predict the energy values of CDs for broilers.

Meta-analysis can yield accurate prediction equations to calculate the AMEn values of feedstuffs. Specifically, a meta-analysis combines the results of several studies that address a set of related research hypotheses, thus increasing the statistical power of the conclusion (Fagard et al., 1996; Nascimento et al., 2011a). According to Mariano et al. (2012), the use of differentiated meta-analysis, combined with the main components technique (MCT), is very efficient, resulting in equations with greater precision and accuracy as confirmed in the present work. According to Mariano et al. (2012), the MCT represents an adaptation to the conventional meta-analysis that facilitates the formation of various groups that compose it.

Based on the results of the present study, it was possible to verify by linear regression the proximity of the points generated by the observed and predicted values of AMEn
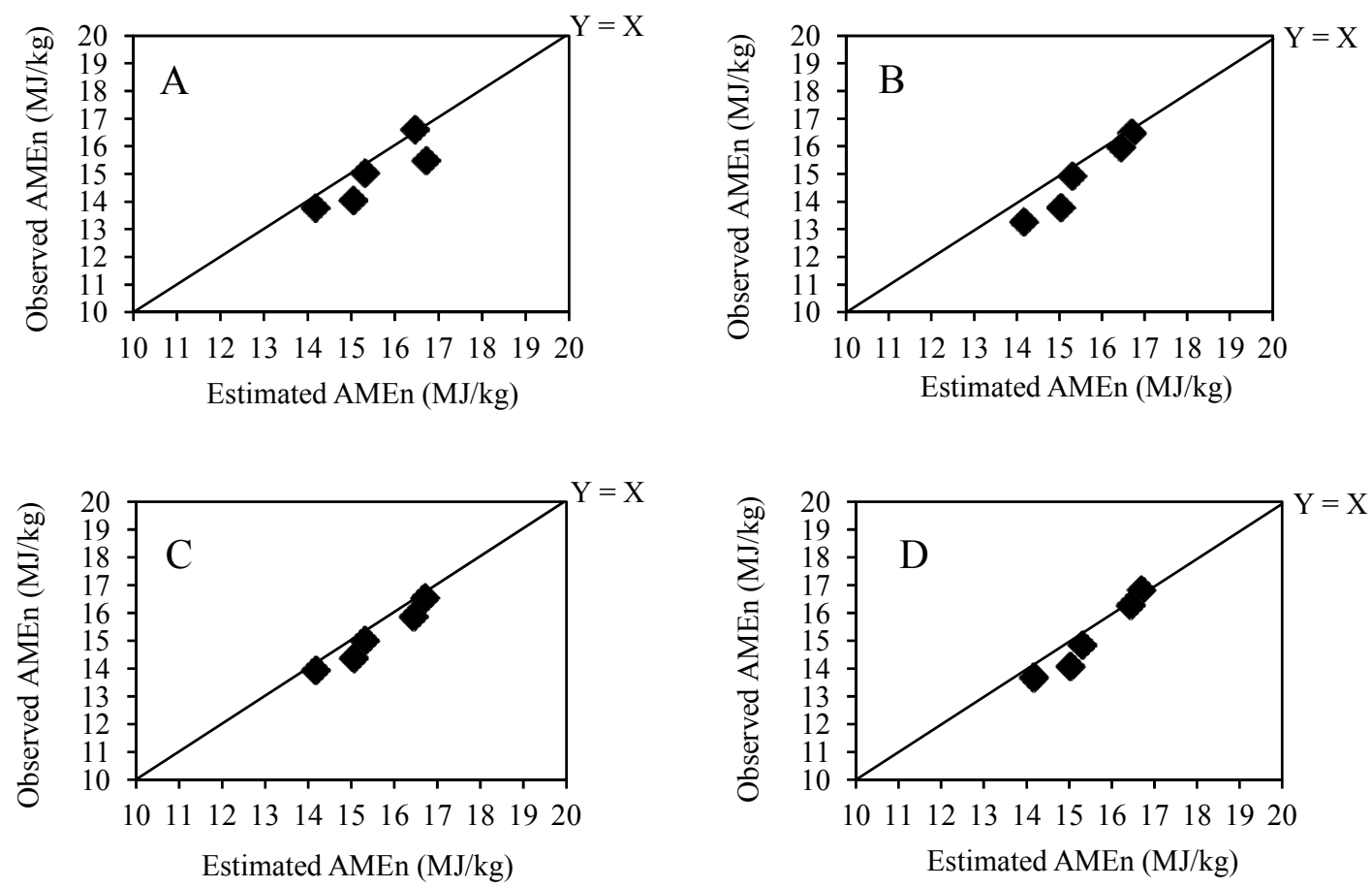

Figure 1. Relationship between the observed and predicted AMEn values of different feedstuffs evaluated in broilers of different age groups: 1 to 7 (A), 8 to 21 (B), 22 to 35 (C), and 36 to 42 days (D). The prediction equation used was previously proposed by Mariano et al. (2012): AMEn = 4,144.914+53.137EE-204.644ash-26.214CF-20.26NDF. AMEn, nitrogen-corrected apparent metabolizable energy; $\mathrm{EE}$, ether extract; $\mathrm{CF}$, crude protein; NDF, neutral detergent fiber. 

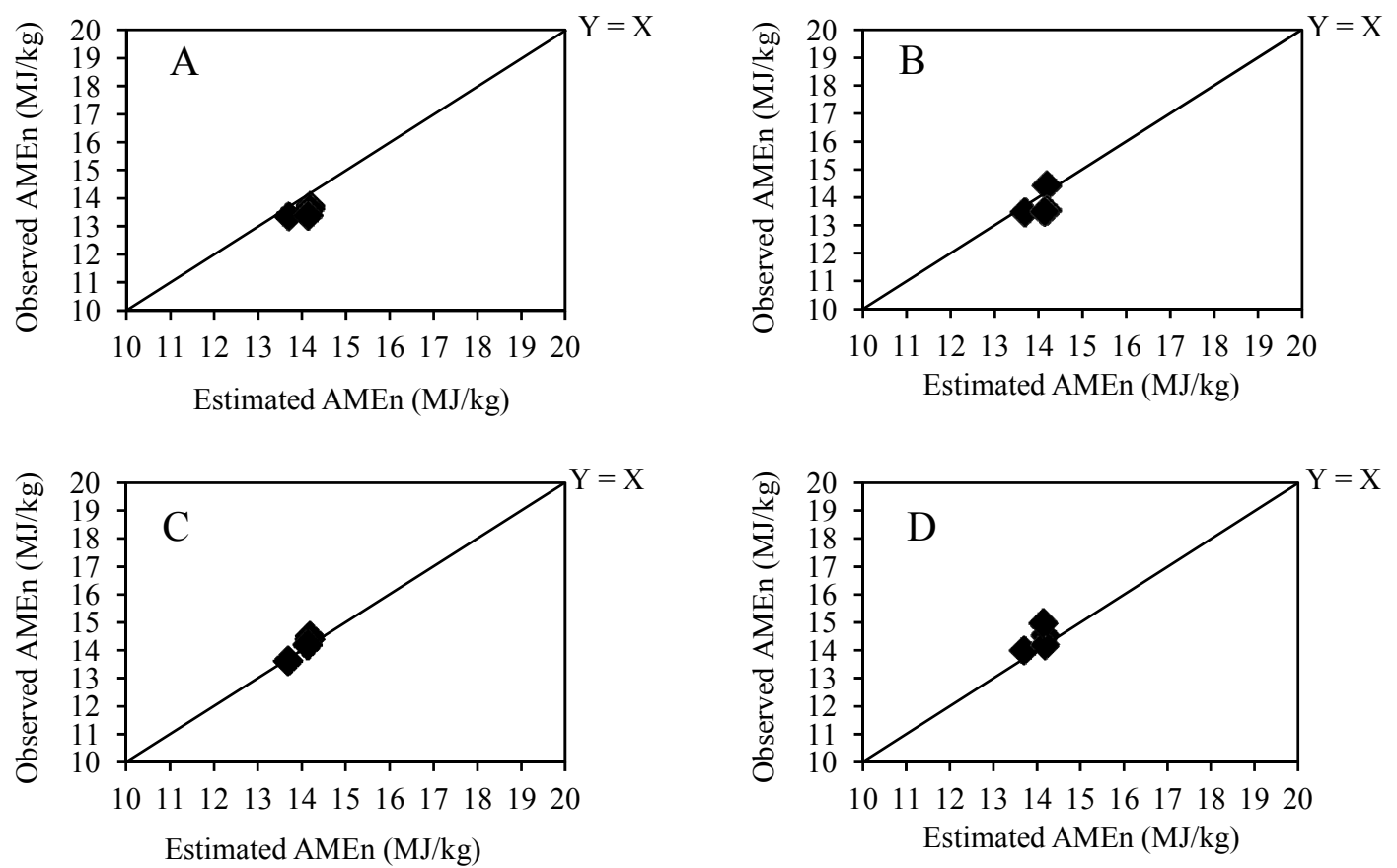

Figure 2. Relationship between the observed and predicted AMEn values of different diets in broilers of different age groups: 1 to 7 (A), 8 to 21 (B), 22 to 35 (C) and 36 to 42 days (D). The prediction equation used was previously proposed by Mariano et al. (2012): AMEn = 4,144.914+53.137EE-204.644ash-26.214CF-20.26NDF. AMEn, nitrogen-corrected apparent metabolizable energy; EE, ether extract; $\mathrm{CF}$, crude protein; NDF, neutral detergent fiber.

along the equality axis $(\mathrm{Y}=\mathrm{X}$, Figures 1 and 2$)$. However, it is important to emphasize that the regressions only show that there is a similarity between the observed and estimated values and do not indicate which prediction equation better fits the data between estimated and observed values (Tedeshi, 2006). The acceptance of the null hypothesis in the present study implies that all prediction equations tested adequately estimated values of AMEn of feedstuffs. However, the estimate precision was different. In other words, the efficiency of an equation to estimate the energy values is not only related to the accuracy $(\mathrm{X}=\mathrm{Y})$ but also related to the precision. The differences in the accuracy and precision between the equations are related to the number of variables that compose the equations and the different calculation techniques used to obtain the equations.

The prediction equation proposed by Mariano et al. (2012) using the differentiated meta-analysis, which accounted for EE, ash, CF, and NDF, was more efficient. EE can also be considered an important variable responsible for the energy variability of the feedstuffs (Zhang et al., 1994; Alvarenga et al., 2011). Garnsworthy et al. (2000) reported that ash is also important for the energy content of feedstuffs because it indirectly represents the organic fraction. Regarding NDF, Wan et al. (2009) evaluated the use of prediction equations to determine the energy values of wheat and its sub-products for ducks. The authors demonstrated that an equation accounting only for NDF explained $94 \%$ of the variation in the energy values for these feedstuffs. Nevertheless, Carre et al. (1984) mentioned that the NDF did not include all indigestible carbohydrates in broilers, citing the pectic substances in the cellular wall as an example. According to these authors, others variables must be included in the prediction equations. Mariano et al. (2012) reported that the inclusion of $\mathrm{CF}$ as a variable in certain prediction equations could subsequently increase the $R^{2}$ value.

The results obtained in the current study show that prediction equations may be more effective in estimating the AMEn values of individual feedstuffs and diets for broilers at different ages. We have shown that these prediction equations are important for increasing the accuracy of diet formulation, allowing producers to correct energy values based on the variations in the chemical composition of feedstuffs. However, more studies are required to reduce the number of variables present in the equation with a minimal loss of accuracy in the estimation of AMEn to facilitate the process of calculating the energy values of foods.

In this study, we found significant variation in the chemical composition of food and energy used for male broilers. The prediction equation AMEn (DM basis) = $4,164.187+51.006 \mathrm{EE}$ (\% in DM basis)-197.663ash35.689CF (\% in DM basis)-20.593 NDF (\% in DM basis) $\left(\mathrm{R}^{2}=0.75\right)$ was the most applicable for the potential 
prediction of the energy values of ingredients commonly used for male broilers in the poultry feed industry.

\section{ACKNOWLEDGMENTS}

The authors thank the Fundação de Amparo à Pesquisa do Estado de Minas Gerais (FAPEMIG), Conselho Nacional de Desenvolvimento Científico e Tecnológico (CNPq) (process number 150295/2012-0) and Instituto Nacional de Ciência e Tecnologia em Ciência Animal - INCT-CA (Viçosa, MG, Brazil) for the financial support for this study.

\section{REFERENCES}

AOAC. 1995. Official Methods of Analysis, 16th ed. Association of Official Analytical Chemists, Arlington, VA, USA.

Alvarenga, R. R., P. B. Rodrigues, M. G. Zangeronimo, R. T. F. Freitas, R. R. Lima, A. G. Bertechini, and E. J. Fassani. 2011. Energetic values of feedstuffs for broilers determined with in vivo assays and prediction equations. Anim. Feed Sci. Technol. 168:257-266.

Alvarenga, R. R., P. B. Rodrigues, M. G. Zangeronimo, L. Makiyama, E. C. Oliveira, R. T. F. Freitas, R. R. Lima, and V. M. P. Bernardino. 2013. Validation of prediction equations to estimate the energy values of feedstuffs for broilers: performance and carcass yield. Asian Australas. J. Anim. Sci. 26:1474-1483.

Anuradha, Y., S. Parminder, and S. S. Sikka. 2013. Relationship between buffering capacity and chemical composition of poultry feedstuffs. J. Kr. Vig. 2:52-54.

Batal, A. and N. Dale. 2012. Feedstuffs: ingredient analysis table: 2009 edition. University of Georgia, Athens, Greece. Available: http://fdsmagissues.feedstuffs.com/fds/Reference_issue_2012/ 03_Ingredient $\% 20$ Analysis\%20Table\%202012\%20Edition.pdf. Accessed July 14, 2013.

Carre, B., B. Prevotel, and B. Leclercq. 1984. Cell wall content as a predictor of metabolizable energy value of poultry feedingstuffs. Br. Poult. Sci. 25:561-572.

Chadd, S. A. 2008. Future trends and developments in poultry nutrition. In: Poultry in the 21st Century: Avian Influenza and Beyond. UN Food and Agriculture Organisation (FAO) International Poultry Conference. Bangkok, Thailand.

Cobb 500, 2008a: Broiler Management Guide. Cobb-Vantress, Guapiaçu-SP, Brazil.

Corduk, M., N. Ceylan, and F. Ildiz. 2007. Effects of dietary energy density and L-carnitine supplementation on growth performance, carcass traits and blood parameters of broiler chickens. S. Afr. J. Anim. Sci. 37:65-73.

Dourado, L. R. B., J. C. Siqueira, N. K. Sakomura, S. R. F. Pinheiro, S. M. Marcato, J. B. K. Fernandes, and J. H. V. Silva. 2010. Poultry feed metabolizable energy determination using total or partial excreta collection methods. Rev. Bras. Cienc. Avic. 12:129-132.

Fagard, R. H., J. A. Staessen, and L. Thijs. 1996. Advantages and disadvantages of the meta-analysis approach. J. Hypertens. 14: 9-13.

Farrel, D. J. 1978. Rapid determination of metabolizable energy of foods using cockerels. Br. Poult. Sci. 19:303-308.

Frikha, M., M. P. Serrano, D. G. Valencia, P. G. Rebollar, J. Fickler, and G. G. Mateos. 2012. Correlation between ileal digestibility of amino acids and chemical composition of soybean meals in broilers at 21 days of age. Anim. Feed Sci. Technol. 178:103114 .

Garnsworthy, P. C., J. Wiseman, and K. Fegeros. 2000. Prediction of chemical, nutritive and agronomic characteristics of wheat by near infrared spectroscopy. J. Agric. Sci. 135:409-417.

Hill, F. W. and D. L. Anderson. 1958. Comparison of metabolizable energy and productive energy determinations with growing chicks. J. Nutr. 64:587-603.

Lesson, S. and J. D. Summers. 1997. Commercial Poultry Nutrition, 2nd ed. University of Books, Guelph, ON, Canada. 350. p.

Longland, A. C. 1991. Digestive enzyme activities in pigs and poultry. In: In Vitro Digestion for Pigs and Poultry (Ed. M. F. Fuller). CAB International, Wallingford, UK. pp. 3-18.

Mariano, F. C. M. Q., R. R. Lima, P. B. Rodrigues, R. R. Alvarenga, and G. A. J. Nascimento. 2012. Prediction equations of energetic values of feedstuffs obtained using meta-analysis and principal components. Cienc. Rural 42: 1634-1640. (Abstr. in English).

Matterson, L. D., L. M. Potter, M. W. Stutz, and E. P. Singsen. 1965. The metabolizable energy of feed ingredients for chickens (Research Report, 7). Agric. Exp. Station, University of Connecticut, Storrs, CT, USA. p. 11-14.

Mayer, D. G., M. A. Stuart, and A. J. Swain. 1994. Regression of real-world data on model output: an appropriate overall test of validity. Agric. Syst. 45:93-104.

Min, Y. N., J. S. Shi, F. W. Wei, H. J. Wang, X. F. Hou, Z. Y. Niu, and F. Z. Liu. 2012. Effects of dietary energy and protein on growth performance and carcass quality of broilers during finishing phase. J. Anim. Vet. Adv. 11:3652-3657.

Murugesan, G. R., B. J. Kerr, and M. E. Persia. 2013. Evaluation of energy values of various oil sources when fed to broiler chicks. Anim. Ind. Rep. AS 659, ASL R2804.

Nascimento, G. A. J., P. B. Rodrigues, R. T. F. Freitas, A. G. Bertechini, R. R. Lima, and L. E. A. Pucci. 2009. Prediction equations to estimate the energy values of plant origin concentrate feeds for poultry utilizing the meta-analysis. Rev. Bras. Zootec. 38:1265-1271. (Abstr. in English).

Nascimento, G. A. J., P. B. Rodrigues, R. T. F. Freitas, R. V. Reis Neto, R. R. Lima, and I. B. Allaman. 2011a. Prediction equations to estimate metabolizable energy values of energetic concentrate feedstuffs for poultry by the meta-analysis process. Arq. Bras. Med. Vet. Zootec. 63:222-230. (Abstr. in English).

Nascimento, G. A. J., P. B. Rodrigues, R. T. F. Freitas, I. B. Allaman, R. R. Lima, and R. V. Reis Neto. 2011b. Prediction equations to estimate the AMEn values of protein feedstuffs for poultry utilizing meta-analysis. Rev. Bras. Zootec. 40:2172-2177. (Abstr. in English).

NRC (National Research Council). 1994. Nutrient Requirements of Poultry, 9th ed. National Academy Press, Washington, DC, USA.

Neter, J., W. Wasserman, and M. Kutner. 1985. Applied linear statistical models. Regression, Analysis of Variance, and Experimental Design, 2nd ed. Irwin, Homewood, IL, USA. 
Nunes, J. O., A. G. Bertechini, J. A. G. Brito, L. Makiyama, F. R. Mesquita, and C. M. Nishio. 2012. Evaluation of cysteamine associated with different energy patterns in diets for broiler chickens. Rev. Bras. Zootec. 41:1956-1960.

Rostagno, H. S., L. F. T. Albino, J. L. Donzele, P. C. Gomes, R. F. Oliveira, D. C. Lopes, A. S. Ferreira, and S. L. T. Barreto. 2005. Brazilian Tables for Poultry and Wwine: Composition of Feedstuffs and Nutritional Requirements, 2nd ed. Federal University of Viçosa, Viçosa, p. 181.

Rostagno, H. S., L. F. T. Albino, J. L. Donzele, P. C. Gomes, R. F. Oliveira, D. C. Lopes, A. S. Ferreira, S. L. T. Barreto and R. F. Euclides. 2011. Brazilian tables for poultry and swine: Composition of feedstuffs and nutritional requirements. Third ed. Federal University of Viçosa, Viçosa, Brazil. p. 252.

SAS Institute Inc. 2004. STAT User's Guide. version 9.00. 4th edn. Cary, NC, USA.

Sibbald, I. R. 1976. A bioassay for true metabolizable energy in feedingstuffs. Poult. Sci. 55:303-308.

Sibbald, I. R. and S. J. Slinger. 1963. A biological assay for metabolizable energy in poultry feed ingredients together with findings which demonstrate some of the problems associated with the evaluation of fats. Poult. Sci. 42:313-325.
Silva, E. P., C. B. V. Rabello, M. B. Lima, E. M. F. Arruda, J. V. Ludke, and M. C. M. M. Ludke. 2012. Determination of the chemical composition, amino acid levels and energy values of different poultry offal meals for broilers. Rev. Bras. Cienc. Avic. 14:97-107.

Tedeschi, L. O. 2006. Assessment of the adequacy of mathematical models. Agric. Syst. 89:225-247.

Van Soest, P. J., J. B. Robertson, and B. A. Lewis. 1991. Methods for dietary fiber, neutral detergent fiber, and nonstarch polysaccharides in relation to animal nutrition. J. Dairy Sci. 74:3583-3597.

Wan, H. F., W. Chen, Z. L. Qi, P. Peng, and J. Peng. 2009. Prediction of true metabolizable energy from chemical composition of wheat milling by-products for ducks. Poult. Sci. 88:92-97.

Wongsuthavas, S., S. Terapuntuwat, W. Wongsrikeaw, S. Katawatin, C. Yuangklang, and A. C. Beynen. 2008. Influence of amount and type of dietary fat on deposition, adipocyte count and iodine number of abdominal fat in broiler chickens. J. Anim. Physiol. Anim. Nutr. 92:92-98.

Zhang, W. J., L. D. Campbell, and S. C. Stothers. 1994. An investigation of the feasibility of predicting nitrogen-corrected true metabolizable energy (TMEn) content in barley from chemical composition and physical characteristics. Can. J. Anim. Sci. 74:355-360. 